\title{
CASE COMMENT: PERSONA NON GRATA: THE SUPREME COURT OF CANADA FURTHER CONSTRAINS PUBLIC INTEREST STANDING'
}

\author{
PETER BOWAL 'AND MARK CRANWELL ••
}

\section{INTRODUCTION}

The recent case of Hy and Zel's Inc. v. The Attorney-General for Ontario; Paul Magder Furs Ltd. v. The Attorney-General for Ontario ${ }^{2}$ demonstrates a further retreat from the once flexible and liberal approach to public interest standing in Canada. Standing has evolved from a strict test found at the time of Macllreith v. Hart, ${ }^{3}$ where the intervention of the Attorney-General was required, to one which opened the doors of justice to parties who were genuinely interested. This approach has its genesis in the trilogy of cases: Thorson v. Attorney-General of Canada (No. 2) ${ }^{4}$, Nova Scotia Board of Censors v. McNeil ${ }^{5}$ and Minister of Justice of Canada v. Borowski. ${ }^{6}$ However, with

- Associate Professor (Business Law), Faculty of Management, University of Calgary.

- Third Year Law Student, University of Alberta.

1 The financial assistance of the Law for the Future Fund of the Canadian Bar Association is acknowledged and gratefully appreciated by the authors. [1993] 3 S.C.R. 675, (1994) 107 D.L.R. (4th) 634, (1993) 160 N.R. 161, 18 C.R.R. (2d) 99, 67 O.A.C. 81 [hereinafter Hy and Zel's cited to D.L.R.].

(1908), 39 S.C.R. 657. The question in this case was whether a resident and ratepayer who alleged misappropriation of public funds (reimbursement of expenses without express authority) could sue the municipality in his own name or whether the action had to be brought by the Attorney-General. The ratepayer could not establish exceptional personal prejudice from the alleged misappropriations. In any event, the court found "such special and peculiar damage" so as to permit the suit in equity. Per Davies J. at 663-64:

The peculiar damage sustained by the ratepayers as a result of such misappropriation, arises out of the increased rates which they will have to pay by reason of the misappropriation of the moneys of the corporation. It matters not whether the damage be great or small, unless indeed the whole transaction was so trivial that the court would refuse to interfere on that ground. But the broad contention is put forward that even where personal misappropriation of the corporate funds by the officers of the municipality is shewn, coupled with the refusal by the controlling officials of the use of the corporate name to enable the wrong to be rectified, the ratepayers are helpless unless and until they can get the Attorney-General to intervene; and that any special damage which the plaintiffs individually or as a special class will sustain cannot and does not give them a right to sue.

The misappropriation here complained of is only $\$ 270$. If it was $\$ 2,700$, it should not make any difference in the determination of the right of the injured class to sue for their own protection. As ratepayers, they seem to have suffered special and peculiar damage to themselves distinct from the public damage which the Attorney-General has the sole right to represent, and, as a result of such special and peculiar damage, have a right to sue in their own name, in equity, to have the wrong rectified or proposed wrong enjoined, where their trustee (the municipality) refuses to allow the corporate name to be used for the purpose [emphasis added].

[1975] I S.C.R. 138, 1 N.R. 225, (1974), 43 D.L.R. (3d) 1 [hereinafter Thorson].

[1976] 2 S.C.R. 265, (1975), 55 D.L.R. (3d) 632, 32 C.R.N.S. 376, 12 N.S.R. (2d) 85, 5 N.R. 43

[hereinafter $\mathrm{McNeil}$. 
the decision in Canadian Council of Churches v. Canada (Minister of Employment and Immigration)' and now Hy and Zel's, the Supreme Court appears to be closing the door once swung wide open to public interest parties.

\section{THE FACTS}

The facts in any standing case are important to show the parties' interests in the constitutionality of the impugned legislation. However, as it turned out, in Hy and $Z e l ' s$, the facts were more procedural than substantive in nature.

The Retail Business Holidays $A c t^{8}$ of Ontario restricts merchants from opening for business on certain designated holidays. Despite the Supreme Court of Canada ruling in Edwards Books ${ }^{9}$ that this statute was constitutional, many store owners ignored the decision and their stores illegally remained open for business on specified holidays. One such store was operated by Paul Magder Furs Ltd. ("Magder"). In December 1989, the Attorney-General for Ontario applied under section 8 of the Act $^{10}$ for an order to compel Magder and two other stores to close on the upcoming holidays of Christmas Eve, Christmas Day and Boxing Day.

Magder responded by bringing a civil application against the Attorney-General and the Toronto police requesting inter alia a declaration that section 2(2) of the $A c t^{11}$ was unconstitutional as violating religious and equality rights under the Canadian Charter

[1981] 2 S.C.R. 575, (1981), 130 D.L.R. (3d) 588, 64 C.C.C. (2d) 97, 24 C.R. (3d) 352, 24 C.P.C. 62, [1982] 1 W.W.R. 97, 12 Sask. R. 420, 39 N.R. 331, 7 W.C.B. 39 [hereinafter Borowski cited to S.C.R.].

7 [1992] 1 S.C.R. 236, (1992), 88 D.L.R. (4th) 193, 2 Admin. L.R. (2d) 229, 5 C.P.C. (3d) 20, 8 C.R.R. (2d) 145, $16 \mathrm{Imm}$. L.R. (2d) 161, 132 N.R. 241, 49 F.T.R. 160n, 31 A.C.W.S. (3d) 214 [hereinafter Canadian Council of Churches, cited to S.C.R.].

R.S.O. 1980, c. 453, as amended.

$9 \quad$ R. v. Edwards Books and Art Ltd. [1986] 2 S.C.R. 713, (1986), 35 D.L.R. (4th) 1, 30 C.C.C. (3d)

385, 55 C.R. (3d) 193, 86 C.L.L.C. ๆ14,001, 28 C.R.R. 1, 71 N.R. 161, 58 O.R. (2d) 442n [hereinafter Edwards Books].

so The provision reads as follows:

8(1) Upon application of counsel for the Attomey-General or of a municipality to the Supreme Court, the court may order that a retail business establishment close on a holiday to ensure compliance with this Act or a by-law or regulation under this Act.

(2) An order under subsection (1) is in addition to any other penalty that may be imposed and may be made whether or not proceedings have been commenced in the Provincial Offences Court for a contravention of section 2 or of a by-law or regulation under this Act.

2(1) No person carrying on a retail business in a retail business establishment shall,

(a) sell or offer for sale goods or services therein by retail; or

(b) admit members of the public thereto,

on a holiday.

(2) No person employed by or acting on behalf of a person carrying on a retail business in a retail business establishment shall,

(a) sell or offer for sale any goods or services therein by retail; or

(b) admit members of the public thereto,

on a holiday.

Section 7 describes the penalties for violation. See infra note 30 for text. 
of Rights and Freedoms. ${ }^{12}$ Magder requested that both applications be heard together. Magder relied on the material filed by the Crown in the section 8 application, offering no evidence of its own.

Both matters were stayed pending the decision in Peel (Regional Municipality) v. Great Atlantic \& Pacific Co. of Canada, ${ }^{13}$ which involved similar facts. In addition to the adjournment, an interim section 8 order was granted, ${ }^{14}$ which expressly required Magder to close on the holidays prescribed by the Act because of the alleged flagrant and continual breaches of the Act on the part of this store. Magder's appeal of the interim order on jurisdictional grounds to the Ontario Court of Appeal was dismissed. $^{15}$

Despite the order, Magder opened for business during the designated holidays and was subsequently found in contempt of court. This contempt decision was appealed but the Ontario Court of Appeal adjourned the appeal sine die until Paul Magder Furs Ltd. obeyed the Act and the restraining order. ${ }^{16}$

The other party to the litigation, Hy and Zel's, was also the subject of a section 8 application in December 1989. In response, Hy and Zel's applied for a declaration that section 2(2) of the Act was invalid. In 1991, Hy and Zel's and over 100 of its employees renewed its application against the Attorney-General, relying on material filed in Peel and some sparse affidavit evidence, seeking the same relief.

The Ontario Court of Appeal, in deciding Peel later that year, found the Act to be constitutional. ${ }^{17}$ The Court of Appeal allowed the Magder and Hy and Zel's appeals to be expedited and dismissed them on the basis of Peel..$^{18}$ Based on this procedural

Canadian Charter of Rights and Freedoms, Part I of the Constitution Act, 1982, being Schedule B to the Canada Act 1982 (U.K.), 1982, c. 11 [hereinafter Charter].

13 (1991), 2 O.R. (3d) 65 (C.A.), reversing (1990), 73 O.R. (2d) 289 (H.C.), (leave to appeal granted sub nom. Oshawa Group Lid. v. Attorney-General of Ontario, [1991] 3 S.C.R. x) [hereinafter Peel].

14 Ontario (Attorney-General) v. Paul Magder Furs Lid. (1989), 71 O.R. (2d) 513 (H.C.) at 520 and 524.

is This was done on October 22, 1991. See supra note 2 at 658.

16 Ontario (Attorney-General) v. Paul Magder Furs Ltd. (1991), 6 O.R. (3d) 188 (C.A.) [hereinafter Magder], leave to the Supreme Court of Canada refused, [1992] 2 S.C.R. ix. In October 1991, Magder applied to bring the section 8 application back on for hearing. Again the application was denied due to the store's ongoing contempt of the interim order: Ontario (Attorney-General) v. Paul Magder Furs Lid. (1991), 5 O.R. (3d) 560 (Gen. Div.).

17 (1991), 2 O.R. (3d) 65 (C.A.). Peel was appealed to the Supreme Court of Canada, but had not been heard prior to the hearing in Hy and Zel's, and was discontinued prior to judgment. See Notice of Discontinuance of Appeal filed August 31, 1993, S.C.C. Bulletin at 1493.

Potts J. stated:

I am advised that counsel for the applicants was also counsel for $A$ \& $P$ and a number of its employees in an application which was ultimately heard and determined by the Ontario Court of Appeal in Peel (Regional Municipality) v. Great Atlantic \& Pacific Co. of Canada Lid.... Mr. Danson has advised that the Hy and Zel's Inc. employee application is indistinguishable from the A \& P employee application (No. 920/90) dismissed by the Ontario Court of Appeal, supra. For the reasons given by that Court, this application is also dismissed, without costs (as quoted 
disposition, leave was granted to both parties to appeal to the Supreme Court of Canada.

\section{THE MAJORITY DECISION}

Major J. wrote the brief majority decision which treats the case as a simple application of public interest standing doctrine. ${ }^{19} \mathrm{He}$ focused exclusively on the threshold issue of standing, although it was not an issue raised in the lower courts. ${ }^{20}$ As well, he observed that Magder had "worn a wide path to the courthouse over the past ten years, "21 an irrelevant reference which could not bolster Magder's chances of success in the court. ${ }^{22}$ Indeed, the majority may have considered these two retail stores more as lawless irritations than as parties legitimately.questioning the constitutionality of the Retail Business Holidays Act. This sentiment may have been one of the undercurrents which drove the majority to the conclusion that the parties lacked standing.

To begin, Major J. stated that a "party's ability to attack a legislation's constitutional validity on Charter grounds is more difficult to establish in a civil suit than in a criminal prosecution. ${ }^{123}$ This admonition was gratuitous as standing to challenge the constitutionality of legislation as a sidebar to a criminal prosecution is a right. It is private standing and will be granted even in the face of other complications such as where the applicant does not qualify for protection under the legislation. ${ }^{24}$ The

by Major J., supra note 2 at 659 ).

19 Lamer C.J.C. and La Forest, Sopinka, Gonthier, Cory and Iacobucci JJ. concurring.

20 Major J. justified this ibid. at 662 by quoting en passant Le Dain J. in The Minister of Finance v. Finlay, [1986] 2 S.C.R. 607, (1986), 33 D.L.R. (4th) 321 (at 328), [1987] 1 W.W.R. 603, 17 C.P.C. (2d) 289, 71 N.R. 338 [hereinafter Finlay, cited S.C.R.]:

[A] court's ability to consider standing at the outset "depends on the nature of the issues raised and whether the court has sufficient material before it, in the way of allegations of fact, considerations of law, and argument, for a proper understanding at a preliminary stage of the nature of the interest asserted." Since the appellants' case has proceeded without trial, the situation is akin to determining standing as a preliminary point.

This rationale is clearly flawed. If standing is not raised in early court applications and decisions are rendered, even without a full trial, it must be implicitly ceded. If the court is concerned with effective utilization of judicial resources, one must question the wisdom of denying standing in a reasoned judgment at the level of the Supreme Court of Canada in favour of another more "reasonable and effective manner of bringing the issue before the court."

$21 \quad$ Ibid. at 657.

22 In contrast, L'Heureux-Dube $J$. preferred to focus on the true issue of constitutionality of the legislation. She cited Big M Drug Mart Ltd. (1985), 18 D.L.R. (4th) 321, 18 C.C.C. (3d) 385, [1985] 1 S.C.R. 295 (at 314), 85 C.L.L.C. ๆ14,023, 13 C.R.R. 64, [1985] 3 W.W.R. 481, 60 A.R. 161, 37 Alta. L.R. (2d) 97, 58 N.R. 81 [hereinafter Big M], where Dickson C.J.C., as he then was, said: "It is the nature of the law, not the status of the accused, that is in issue."

23 Supra note 2 at 660 .

24 See e.g. Big $M$ and $R$. v. Wholesale Travel Group Inc. (1991), 84 D.L.R. (4th) 161, 67 C.C.C. (3d) 193, 38 C.P.R. (3d) 451, [1991] 3 S.C.R. 154, 8 C.R. (4th) 145, 7 C.R.R. (2d) 36, 49 O.A.C. 161, 130 N.R. 1, 4 O.R. (3d) 799n, 30 A.C.W.S. (3d) 660, 14 W.C.B. (2d) 208. 
Supreme Court of Canada in numerous decisions has granted standing to parties using the Charter in civil cases. ${ }^{25}$

The first sign that the Supreme Court of Canada was seeking to retreat on public interest standing came in Canadian Council of Churches. ${ }^{26}$ In Hy and Zel's, Major J. quoted the caution that Cory J. had expressed in that decision:

I would stress that the recognition of the need to grant public interest standing in some circumstances does not amount to a blanket approval to grant standing to all who wish to litigate an issue. It is essential that a balance be struck between ensuring access to the courts and preserving judicial resources. It would be disastrous if the courts were allowed to become hopelessly overburdened as a result of the unnecessary proliferation of marginal or redundant suits brought by a [sic] well-meaning organizations pursuing their own particular cases certain in the knowledge that their cause is all important. It would be detrimental, if not devastating, to our system of justice and unfair to private litigants.... The granting of public interest standing is not required when, on a balance of probabilities, it can be shown that the measure will be subject to attack by a private litigant. The principles for granting public standing set forth by this Court need not and should not be expanded. ${ }^{27}$

Moving from this caution about public interest standing, Major J. outlined the Borowski or "trilogy" criteria to determine standing:

Following this Court's earlier decisions, in order that the Court may exercise its discretion to grant standing in a civil case, where, as in the present case, the party does not claim a breach of its own rights under the Canadian Charter of Rights and Freedoms but those of others, (1) there must be a serious issue as to the Act's validity, (2) the appellants must be directly affected by the $A c t$ or have a genuine interest in its validity, and (3) there must be no other reasonable and effective way to bring the $A c t$ 's validity before the court. ${ }^{28}$

In applying these criteria to the facts in these cases, Major $\mathrm{J}$. found a serious issue to the validity of the legislation. Even though the Act was facially constitutional, the numerous amendments to it might raise new constitutional questions since Edwards Books was decided. ${ }^{29}$

See, for examples, the trilogy, and Conseil du Patronat du Quebec Inc. v. Quebec (AttorneyGeneral), [1991] 3 S.C.R. 685 [hereinafter Counseil du Patronat]. See also J. Ross, "Canadian Council of Churches v. The Queen: Public Interest Standing Takes a Back Seat" (1992) 4 Const. Forum 100.

Supra note 7 at 252.

Supra note 2 at 660-61.

Supra note 9. 
When considering the second criterion, direct effect or genuine interest, Major $\mathrm{J}$. pointed to sections 2 and 7 of the $A c t^{30}$ which specifically identify retail businesses as liable to prosecution. He concludes:

While the Act affects all Ontarians by limiting their ability to make retail purchases on holidays, only retailers and retail employees are subject to prosecution for its violation. The Act clearly has a direct effect on the appellants. ${ }^{31}$

Normally this determination of direct effect, which is more compelling than "genuine interest", would achieve standing for a party as the other two criteria would virtually follow suit. As we will see, the two dissenting justices would have found this direct effect to have constituted sufficient private interest to warrant standing. The development of the locus standi principle is poorly served where judges cannot even agree on whether the circumstances give rise to the vindication of private or public interests. While the Borowski Court stated that "a person need only to show that he is affected by [the legislation] directly or that he has a genuine interest as a citizen," ${ }^{32}$ it did not offer any test as to the degree of direct effect which takes the issue out of the public interest and renders it a private standing matter. ${ }^{33}$

However, Major J. shifted emphasis to the last criterion, that of no other reasonable means of bringing the issue before the Court. The use of the word "reasonable" here allows courts to exercise their discretion, as noted earlier, which used to be exercised very liberally and allowed parties to bring forward an issue notwithstanding there being "better" parties and other means of bringing the issue before the court. ${ }^{34}$ By definition, public interest standing demands a compromise on this criterion. This test serves as the "gate": the stricter the application of this standard, the less public interest organizations will obtain standing, on the basis that there is always a "better" party to bring the case

See supra note 11 for section 2 . Section 7 reads:

7 (1) Every person who contravenes section 2 or a regulation under section 4 is guilty of an offence and on conviction is liable to a fine of not more than the greater of,

(a) $\$ 50,000$; or

(b) the gross sales on the retail business establishment on the holiday on which the contravention occurred.

$31 \quad$ Supra note 2 at 662.

$32 \quad$ Supra note 6 at 598.

33 In Finlay, supra note 20, Le Dain J. for the Court, referred to "direct effect" as "personal interest" and distinguished it from "genuine interest" but without clear private and public interest parameters.

34 For example, in Conseil du Patronat, supra note 25, the Supreme Court of Canada adopted the dissenting opinion of Chouinard J.A. of the Quebec Court of Appeal, who would have granted standing to a non-profit corporation that represented numerous employers' associations challenging the anti-strike-breaking provisions of the Quebec Labour Code. Although any one of the association's members could have challenged the provisions since they were directly affected, Chouinard J.A. felt the Conseil du Patronat spoke for its members and therefore had just as much interest as each of its members. Indeed there were other means of bringing the issue before the court but this in itself did not dissuade the Supreme Court of Canada from granting standing. Curiously, the Conseil du Patronat decision is not mentioned by the majority despite being decided close to the time of Canadian Council of Churches. 
to court. ${ }^{35}$ As it started to assume this function in Canadian Council of Churches, this criterion will be increasingly resorted to as the "regulator" - determining on an ad hoc basis which cases will be adjudicated and which will not.

The parties failed on the inquiry as to whether "other reasonable and effective means" existed of bringing the matter to court. The precise reasons are not clear. Major J. suggests that it may be because "almost no original evidence in support of their claim $^{136}$ was presented. Presumably he was motivated by judicial fondness for a clean and comprehensive prosecution file where private standing to defend on constitutional grounds would be unassailable. Deficiency of evidence is a foreseeable defect of the summary procedure followed in this case.

Major J. might be taken, perhaps inadvertently, to elevate this reasonableness-based criterion to an absolute pre-condition when he states: "If there are other means to bring the matter before the court, scarce judicial resources may be put to better use. ${ }^{137}$ The simple existence of other means to bring the issue before the court may thwart a public interest party from attaining standing. There are practical measures which may be taken to augment the court file, including an adjournment to file supplementary materials. It is submitted that resort to such remedial measures would save judicial resources more than dismissing the case on the basis of standing at the Supreme Court of Canada level and awaiting return of the same parties and arguments through the judicial ranks. If so, the Court's view on standing has undergone radical transformation since the crystallization of the trilogy of cases.

And what would be the better or other reasonable means to bring a matter before the court? The question that has to be asked is whether the "other reasonable or effective means" is truly a "better means". In Canadian Council of Churches, the Court denied standing, deciding there were other reasonable means to bring the case to court. Could each individual refugee fully canvass the various constitutional and Charter issues in the Immigration Act amendments? Or would the representative organization of Canadian Council of Churches actually have been "better" at that? In Hy and Zel's the same questions can be posed and have been posed. ${ }^{38}$ Instead of considering the obstacles involved in other parties bringing forward the matter, Major J. notes that the fact the appellants rely on the Peel evidence suggests there may be a more reasonable and effective matter of bringing the issue before the court.

Laskin C.J.C. dissented in Borowski, supra note 6, on this ground, once he saw that the field of public interest litigation was too open.

Supra note 2 at 662 .

Ibid. [emphasis added].

J. Ross, "Further Restrictions on Access to Charter Review: A Comment on Hy and Zel's Inc. v. Ontario (A.-G.)" (1994) 5 Const. Forum 22 at 23. The author notes:

The court should consider who potential plaintiffs might be and what obstacles they might face.

For example, as discussed in the dissent, while the Charter rights of employees may be affected, they are unlikely to have the political or financial resources to bring their concerns to court. Retailers who belong to minority religions may have the financial wherewithal to challenge the law, but how many such retailers exist? 
It is submitted that "other effective and reasonable means" should be replaced with a "best party" test. The appellants were perhaps the "best party" to bring forward this issue. Both Magder and Hy and Zel's were subject to section 8 orders forcing them to close their stores. They were subject to penalties over and above the other punishments in the Act. These retail businesses were directly affected and they were before the court to challenge the constitutionality of an act that affected their business. If these appellants are not the proper applicants, who then would be a better party? ${ }^{39}$ What are the other reasonable and effective means of bringing this matter before the court?

With respect to optimal utilization of scarce judicial resources, the proper question is how much money is being saved when the Supreme Court of Canada, addressing standing for the first time, gives a reasoned opinion and dismisses the appeal. The message to these litigants is to return later, perhaps by way of a different route or different parties and the Court will then address the constitutionality of the Act. Will this etiquette at a later point in time accomplish that which cannot be met at the present time? Ironically, by refusing standing in these circumstances the Court is squandering judicial resources. ${ }^{40}$ Granting standing in these circumstances can economize on judicial resources by preventing litigants from having to return to court.

Major J. pointed out that the legislation is not insulated from challenge as it was in the case of Borowski: "In contrast to Borowski, the present Act does not discourage challenge." ${ }^{\prime 41}$ The Court instead prevented challenge by not granting standing. Ultimately, the result is the same: government action remains unexamined, although ease of challenging government action was the reason why standing rules were liberalized in the first place.

Major J. appeared to confuse "directly affected" and "genuinely interested". Logic dictates that as a directly affected person, the party will have an easier time showing that there is no other effective or reasonable means to bring the matter before the court. If a party is merely genuinely interested, prima facie there may be others with claims to adjudication that are as good or better than the genuinely interested person. That

Whether corporate accused are indeed the best parties to bring the freedom of religion challenge can be questioned. In criminal proceedings, corporations have been allowed to raise freedom of religion. However, this principle has not been extended to civil proceedings. See e.g., K. Roach, Constitutional Remedies in Canada (Aurora, Ont.: Canada Law Book, 1994) at 5-16 to 5-18.

This point was addressed by L'Heureux-Dube J., who said (supra note 2 at 652):

Particularly where, as in this case, the party seeking standing is already before the courts, great consideration should be given in assessing the benefits of proceeding with the constitutional challenge and the prejudice to the appellants in refusing standing at this late stage in the proceedings ... nothing is to be gained by refusing standing whereas the benefits of granting standing are evident indeed.

And at 654:

But, more importantly, it would unquestionably be prejudicial to the appellants to have been permitted to rely on this record all along, only to be told at this stage that they will be denied standing for this reason. If this was of concem to the court, the appellants should have been denied leave.

4 Ibid. at 663. Cf. Laskin C.J.C.'s dissent in Borowski, wherein he did not think challenge to that Act had been foreclosed. 
person will have a greater onus to show that in each particular case, there is no other more effective or reasonable means to bring the matter forward. In Borowski, it was believed that persons directly affected by the criminal abortion provisions would not challenge it. Therefore, only a party who had a "genuine interest' would raise the issue before the court. In this case, both Magder and Hy and Zel's were directly affected by the statute in question. Even after finding the parties were directly affected, Major J. concluded on the third criterion, that of other reasonable means, "the appellants have failed on this point." ${ }^{142}$

What could be the most serious blow to public law standing was the following statement of the Court: "Nor do the appellants have standing on the basis that their own religious rights have been violated. ${ }^{143}$ It is too early to tell whether this was propounded in error or simply in ambiguous terms. "Direct effect" or "genuine interest" was historically established as the threshold connection for public interest litigation. ${ }^{44}$ If litigants must now show a violation of their own rights, one might inquire what has become of Borowski. What has become of anticipatory and declaratory actions? Most of the public interest cases have been either anticipatory (for example, Operation Dismantle $^{45}$ and Energy Probe ${ }^{46}$ ) or declaratory (e.g. the trilogy cases) or both (e.g. Conseil du Patronat).

Major J.'s statement can be interpreted to wholly eliminate public interest standing, since it is a concept which has its essence in the vindication of the rights of others. If the litigants must show that "their own rights have been violated," is private interest standing all that is left? (7 $^{4}$

The majority emphasized the paucity of evidence and the fact that the appellants relied on material filed in Peel and by the Crown in their own cases. In the relatively rare case where standing is raised, however, it is often decided as a threshold issue without the benefit of full argument from both sides. This procedure is acceptable as only the issue of standing is to be decided and not the substantive legal issues themselves. Deficiency of evidence is a predictable weakness in such summary procedures and one might question the use of standing rules to determine the outcome

$42 \quad$ Ibid.

Ibid. [emphasis added].

4 Or in the words of Peter Hogg, cited ibid. at 639 by L'Heureux-Dube J., to determine whether a person has a "sufficient stake in the outcome to invoke the judicial process": Constitutional Law of Canada, 3d ed. (Toronto: Carswell, 1992) at 1263 [emphasis in judgment].

4s [1985] I S.C.R. 441 [hereinafter Operation Dismantle].

46 Energy Probe v. Canada (Attorney-General) (1989), 58 D.L.R. (4th) 513, 3 C.E.L.R. (N.S.) 262 (Ont. C.A.), leave to appeal to the Supreme Court of Canada refused (1989), 102 N.R. 399n (S.C.C.).

47 The context in which this statement was made once again stressed the importance of deciding these cases in a concrete factual framework. See Major, J. supra note 2 at 663 where he cites the Court in Danson v. Ontario (Attorney-General) (1990), 73 D.L.R. (4th) 686, [1990] 2 S.C.R. 1086, 43 C.P.C. (2d) 165 at 691 (D.L.R.): "[T] he failure of a diffuse challenge could prejudice subsequent challenges to the impugned rules by parties with specific and factually established complaints." It is important to remember that concrete factual backgrounds are rarely found in anticipatory and declaratory cases. 
of this action. ${ }^{48}$ Major J. had enough evidence to satisfy the first two criteria. He conceded that there was a serious issue as to the validity of the Act and that the appellants were directly affected. What more evidence does one need when determining standing? Major J., one respectfully submits, refused to give the case a hearing at all on the basis of the quality and sufficiency of the evidence first. This test is an evidentiary inquiry as to proof and likelihood of success and can be misapplied to decide whether to hear the case at all. Aside from the perversion of legal method that this approach represents, ultimately the "efficient use" of resources could require every case (including all actions based on private standing) to be approached on the basis of the quality and sufficiency of the evidence that is likely to be borne out.

\section{THE DISSENTING OPINION}

The lengthy dissent of L'Heureux-Dube' J., McLachlin J. concurring, did not discuss this case as simply an application of public interest standing doctrine. Instead, she examined the relationship of private and public interest standing and found these plaintiffs to be in a completely different situation than any previous public interest party.

The dissent describes and distinguishes public interest standing, the "trilogy" test, ${ }^{49}$ and the "exceptional prejudice" test found in Smith v. Attorney-General of Ontario. ${ }^{50}$ The latter rule held that in order to challenge a law of general application, a plaintiff is required to show that the effect of the legislation was greater or different on him or her than its effect on the public at large. ${ }^{51}$ L'Heureux-Dube' J. believed that Magder and $\mathrm{Hy}$ and Zel's were "better described as persons who experience 'exceptional prejudice' under the $A c t . "{ }^{152}$ She asks:

[S]hould the rules recently developed by this Court as regards public interest litigants govern those litigants who fall squarely within the rule in Smith? In other words, should the trilogy test bar the standing of those litigants who would otherwise benefit from the rule in Smith? ${ }^{33}$

Her dissent would resurrect Smith and apply it where the rule could quickly establish standing if a party is "exceptionally prejudiced", even if "the rules for public interest standing articulated in the trilogy may not be tailored to meet their particular interests

By contrast, L'Heureux-Dubé J., dissenting, distinguished the issue of standing from the question of the sufficiency of evidence, ibid. at 654-55.

49 See page 196 above.

so [1924] S.C.R. 331, 3 D.L.R. 189, 42 C.C.C. 215 [hereinafter Smith].

st Le Dain J. in Finlay, supra note 20 at 618 stated that the trilogy itself is a departure from the general rule and that one should always first consider if the party has a sufficient interest before applying the trilogy test.

s2 Supra note 2 at 645.

33 Ibid. at 645-47, she refers to T.A. Cromwell who, in his text Locus Standi: A Commentary on the Law of Standing in Canada (Toronto: Carswell, 1986) at 82 suggests that:

[T] he result of Thorson and $\mathrm{McNeil}$ was to create a new, discretionary approach to standing that is available for those who do not come within the Smith test of "exceptional prejudice".

For those that do, standing remains as of right [emphasis in original]. 
in the present litigation. ${ }^{154}$ L'Heureux-Dube' J. put the two tests on a spectrum and concluded that if a party were exceptionally prejudiced, it would necessarily gain standing under the trilogy test. ${ }^{55}$ In other words, either the Smith or the trilogy tests could be relied on if either afforded the applicant standing. ${ }^{56}$

The dissenting opinion goes on to urge a continued flexible approach to standing, a generous exercise of judicial discretion. It takes note of the proposals of the British Columbia and Ontario Law Reform Commissions that standing be further extended. Their recommendations would effectively reverse the present onus and formulate the rule so that everyone is "entitled to commence a proceeding unless a party challenging such a right satisfies the court there exist factors against proceeding that outweigh the factors in favour...." ${ }^{57}$ That the two dissenting justices approve of changes which could virtually eliminate standing requirements amply illustrates their view of the "floodgates" and "limited judicial resources" concerns.

L'Heureux-Dube' J., accordingly, found "no principled or practical reason to refuse" standing in this case. ${ }^{58}$ She would have granted private interest standing on the basis that these appellants suffered exceptional prejudice due to the special effect of the legislation against their interests. The affected parties were before the court in an existing controversy and it should have been resolved to avoid a multiplicity of proceedings:

None of the usual concerns which underlie the restrictions on public interest standing is present in this case. The parties most directly affected by the $A c t$ are before the court, there is a live controversy and, as the appellants face numerous outstanding charges in the lower courts, there is no question of burdening the system with another litigant who would otherwise be uninvolved. In fact, granting the appellants standing actually reinforces one of the objectives of the rules of standing, that is, prevention

Ibid. at 645. L'Heureux-Dube J. continues:

The position of the appellants, in contrast to that of the public interest litigant, may be described as follows. The basic thrust of public interest standing is to provide an avenue of access to the courts to those who, because they have no cause of action under traditional rules, lack the means of bringing their concerns before the courts. The expanded rules of public interest were intended to accommodate such persons so that legislation would not be otherwise immunized from attack. However, what litigants such as the appellants seek is standing to argue the constitutionality of a law by which they are directly and particularly affected.

Ibid. at 647 .

L'Heureux-Dube J. cautioned that:

[T] he expansion of public interest standing developed by this Court in [the trilogy] was not designed to restrict access to the courts but to liberalize it. It would be anomalous, if not perverse, to find that a plaintiff who formerly would have succeeded in bringing a constitutional challenge simply by the ability to establish exceptional prejudice under the legislation is now barred due to rigid adherence to a formula designed to serve as a means of sorting out meritorious from less deserving claims to public interest standing. Ibid.

Report on the Law of Standing, Ontario Law Reform Commission (Toronto: Ministry of the Attomey-General, 1989) at 177. L'Heureux-Dube J. noted that the British Columbia Law Reform Commission, in its Report on Civil Litigation in the Public Interest (Vancouver, 1980), recommended a person be permitted to take action for a declaration of invalidity "whether or not the person has an interest in or is directly affected by the enactment." Ibid. at 649.

Ibid. at 656 . 
of a multiplicity of suits, as the numerous outstanding charges against the appellants under the $A c t$ which presently constitute a burden on the administration of justice could be disposed of by a ruling on the constitutional validity of the $A c t .^{59}$

She would also have found public interest standing. ${ }^{60}$

\section{ANALYSIS AND CONCLUSION}

The golden age of liberal public interest standing in Canada is gone. It is difficult to imagine the courthouse gates being ever again opened as wide as they were during the apogee of Borowski. Even other recent Supreme Court of Canada decisions such as Conseil du Patronat (granted standing) and Canadian Council of Churches (denied standing), which were decided only six weeks apart, are hard to reconcile. ${ }^{61}$ In fact, the latter case is now consistently invoked to justify the refusal of standing.

In Hy and Zel's, the majority and dissent in the Supreme Court of Canada were polar opposites in their approaches and conclusions. The respective reasons demonstrate the philosophical chasm that exists with respect to public interest standing and the need to control it. ${ }^{62}$ Their paths diverge when the majority bases its discretion upon insufficiency of evidence and judicial resources, while the dissent would see the appellants as directly and personally interested. This comment argues that the dissenting opinion was more sound in its application of the law, but matters of discretion can be easily snatched from the dominion of law. ${ }^{63}$ This case cannot be taken to advance the

Ibid. at 652-53.

Ross, supra note 38 at 24 points out a problem with private standing in this particular case: "This, however, would have been a barren form of standing, if the Irwin Toy principle denied them [a corporation] the ability to rely on s. 2(a) or s. 15 of the Charter." In the civil (declaration) case of Irwin Toy v. Québec (Attorney-General), [1989] 1 S.C.R. 927, (1989), 58 D.L.R. (4th) 577, 25 C.P.R. (3d) 417, 39 C.R.R. 193, 24 Q.A.C. 2, 94 N.R. 167, 15 A.C.W.S. (3d) 121, the Court stated, obiter, that corporate plaintiffs with private standing could rely on the Charter rights of others. This principle has been confirmed in the penal proceeding before the Court in Wholesale Travel Group Inc. v. The Queen, [1991] 3 S.C.R. 154, (1991), 84 D.L.R. (4th) 161, 67 C.C.C. (3d) 193 (at 211), 38 C.P.R. (3d) 451, 8 C.R. (4th) 145, 7 C.R.R. (2d) 36 [hereinafter Wholesale Travel] where Lamer C.J.C., for the majority of the Court, concluded:

[G]iven that the false/misleading advertising provisions encompass both individual and corporate accused and given this court's interpretation of s. 52(1), Wholesale Travel does have standing to challenge these provisions under ss. 7 and 11 (d) of the Charter and is entitled to benefit from a finding that the provisions violate a human being's constitutional rights [emphasis in judgment].

61

62

See also Operation Dismantle, supra note 45, and Wholesale Travel, ibid.

With respect to judicial resources, L'Heureux-Dube J. closed with this sardonic remark, supra note 2 at 656 :

Given the fact that the majority of this Court has concluded that the appeal should be dismissed, it would not be an efficient use of the Court's limited resources for me to discuss the merits of the case.

The irony in this case is that standing was neither raised by the parties nor judicially considered in the lower courts. As a threshold issue, it might be implied to have been conceded. Not only does the Supreme Court of Canada here interfere with that implied discretion, but it does so on the rationale of saving judicial resources. Rendering a reasoned decision on standing where it was not raised in the lower courts is a false economy. For a classic case of respect of judicial 
formalization of standing principles, ${ }^{64}$ because its facts were so unusual and "bad facts" make for "bad law". Whether Canadian courts confine this decision to its facts remains to be seen. On the other hand, it increases the likelihood that public interest standing will be one of the defensive positions of the Crown in future constitutional litigation. Alas, even this development will likely not have the effect on judicial resources that the Court seeks in this case.

The balance between ensuring access to the courts and preserving judicial resources has tipped in the direction of optimizing resources at the expense of access. The opinion of the majority in $\mathrm{Hy}$ and Zel's puts additional weight in favour of conserving judicial resources. Although it is unlikely to do so, this new emphasis has the potential to alter significantly the ability of public interest litigants to bring issues forward because the effective use of resources test does not significantly advance standing analysis. It is always open to assert that the court could better spend its time on other things. If this concern were permitted to control what cases were heard, courts might never grant standing in public interest cases. Certainly, periodic judicial workloads cannot be the determining factor in which such cases get standing. Moreover, public interest litigation is arguably among the most effective use of resources. ${ }^{65}$

Major J. defended "the Court's vigilance in ensuring that it hears the arguments of the parties most directly affected by a matter." ${ }^{66}$ Nevertheless, this position constitutes a frontal attack on the concept of public interest litigation, and the reason for it in the first place. The lack of a concrete factual context and proponents with a merely circumstantial connection to the action are characteristics of this genre of litigation. To turn away cases lacking specific factual bases and parties because they are not sufficiently directly affected is tantamount to turning away public interest cases because they are public interest cases. In refusing standing to these parties, the Supreme Court of Canada placed an undue emphasis, indeed an illogical one, on the last criterion of public interest standing, that of no other reasonable means to bring the issue before the court. The Court might have considered proposing a fresh doctrine based on agency,

discretion, see Hi-Fi Novelyy v. Nova Scotia (1993), 126 N.S.R. (2d) 70 and 352 A.P.R. 70 (C.A.) where at $73-4$ Chipman J.A. refused to substitute his judgment on standing:

This court has said on several occasions that it will not interfere with a discretionary order, particularly an interlocutory one such as this, unless wrong principles of law have been applied or a patent injustice would result. Simply because we may possibly have reached a decision contrary to that of the judge on the facts is not sufficient. The burden on the appellant is heavy.... In our opinion, the appellants have failed to show that the chambers judge made any error of law or that any patent injustice arose from the decision which he has reached.

It is important to note that the Supreme Court still favoured a generous interpretation of justiciability and "genuine interest".

As for the fear of scarce judicial resources and multiplicity of lawsuits, L'Heureux-Dube J. supra note 2 at $648-49$ notes that Thorson recognized that:

[T] here are enough practical disincentives to litigants by reason of costs and inconvenience to discourage those who have no real stake in the outcome of the litigation from engaging in frivolous lawsuits ... care should be taken not to exaggerate the threat to the justice system by a more liberal approach to standing...

lbid. at 663. 
"best party", or global and intrinsic public policy in lieu of packing its apprehensions about this case into the third trilogy criterion.

A cynic might suggest that the workload concerns and appetites for specific and complete factual backgrounds are pretences for the indulgence of the judge's political preferences. In the tone of several of the more recent judicial decisions, the configuration and modus operandi of the applicants may have been the determining factors as to standing. As tests are refined and formulated, it is submitted that discretion will follow impressions. Standing was refused where the litigant came close to abuse of court process (Magder); or law-breaking ( $\mathrm{Hy}$ and Zel's and Magder); was considered, albeit not labelled, a busybody (Canadian Council of Churches); or was in an insalubrious business such as video gambling (Hi-Fi Novelty); or exhibited hasty and persistent behaviour (Metropolitan Authority) ${ }^{67}$ Nuclear power (Operation Dismantle and Energy Probe) and environmental concerns (Rafferty Alameda, ${ }^{68}$ Reese $^{69}$ and Friends of the Island ${ }^{\circ}$ ) concerns are, on the other hand, more likely to be heard. In many more cases, such as to affirm a provincial tax on alcohol ${ }^{71}$ or the validity of the criminal sanctions against assisted-suicide, ${ }^{2}$ standing was not even raised as an issue.

Public interest litigation is a special transaction because it raises public law questions that might be too diffuse to raise otherwise. Each judge's perspective and abiding willingness to receive the issue for adjudication will determine the requisite degree of direct relationship, issue ripeness and quality of the materials filed. Where most application of law is principled, locus standi has been a classic case of immense, if not virtually unfettered, judicial discretion. Notwithstanding the occasional Supreme Court of Canada pronouncement that it will once more structure this discretion in principle, this issue will continue to be managed by trial judges across the country on the basis of their "feel" for the need for each particular case to be adjudicated.

Public interest standing in Canada, which started with Thorson, almost seems to have come full cycle in twenty years with the decision of $\mathrm{Hy}$ and Zel's. The Supreme Court of Canada may be one case short of a new, decidedly more conservative "trilogy" on the subject. Browsing the law reports today, one nevertheless observes that public interest groups are still getting into court to have their concerns adjudicated. While $\mathrm{Hy}$ and Zel's does constrain public interest standing, it is not likely to drastically reverse the gains in this doctrine over the past two decades.

Coalition of Citizens for a Charter Challenge v. Metropolitan Authority (1994), 12 C.E.L.R. (N.S.) 1 (N.S.C.A.).

Rafferty Alameda v. Saskatchewan (1988), 68 Sask. R. 52, 3 C.E.L.R. (N.S.) 236.

(1992), 7 C.E.L.R. (N.S.) 89, 11 Admin. L.R. (2d) 265 (Alta. Q.B.); additional reasons provided at (1992), 5 Alta L.R. (3d), 133 A.R. 127, 13 C.P.C. (3d) 323, 11 Admin. L.R. (2d) 265N.

Friends of the Island v. Canada (Minister of Public Works) (1993), 102 D.L.R. (4th) 696, 10 C.E.L.R. (N.S.) 204, [1993] 2 F.C. 229, 61 F.T.R. 4.

Brew on Premise Association of Eastern Ontario v. Ontario, (March 21, 1994) Ottawa 558/93 (Ont. Div. Ct.).

Rodriguez v. British Columbia (Attorney-General), [1993] 3 S.C.R. 519, (1993), 107 D.L.R. (4th)

342, 158 N.R. 1, 85 C.C.C. (3d) 15, [1993] 7 W.W.R. 641, 82 B.C.L.R. (2d) 273, 17 C.R.R. (2d)

193, 24 C.R. (4th) 281, 34 B.C.A.C. 1, 56 W.A.C. 1. 